\title{
ŁUKASZ WALAS
}

Instytut Dendrologii PAN

Parkowa 5, 62-035 Kórnik

E-mail: lukaswalas@man.poznan.pl

\section{NIEZWYKŁA HISTORIA ZWYCZAJNEGO KASZTANOWCA}

\section{WPROWADZENIE}

Kasztanowiec zwyczajny (Aesculus hippocastanum L.) (Ryc. 1) jest w Polsce tak

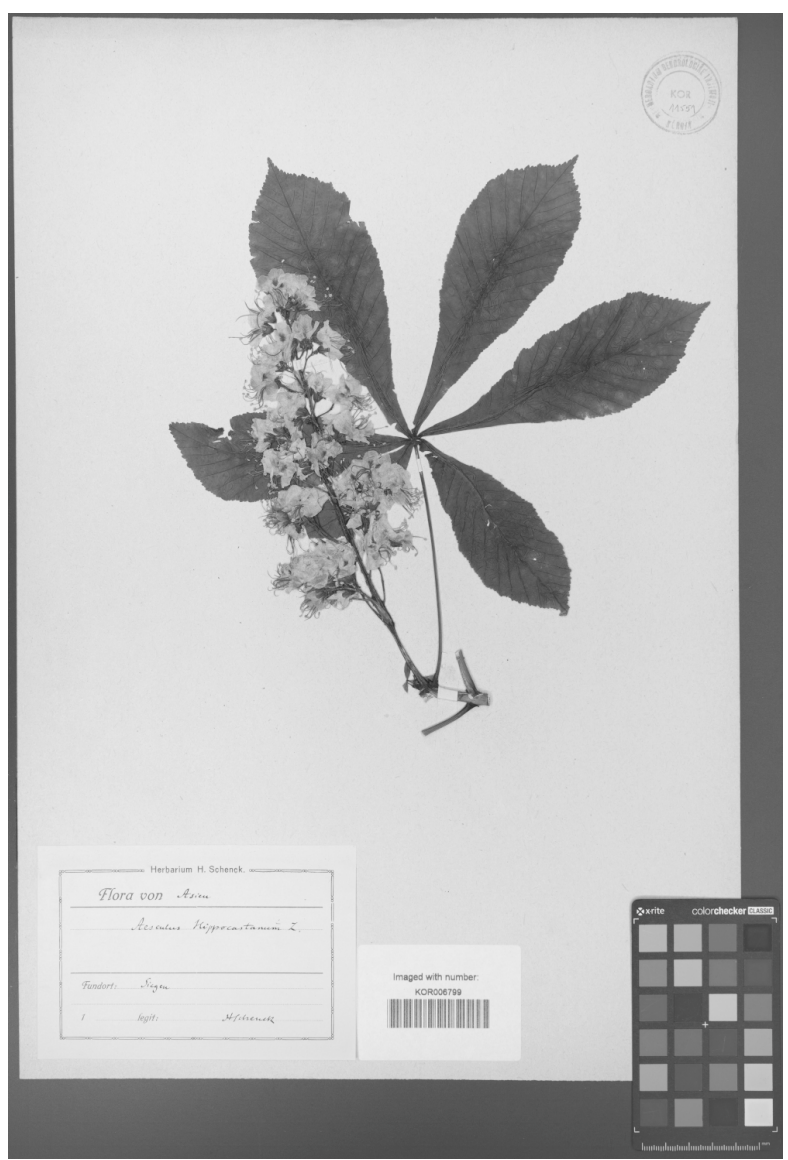

Ryc. 1. Kwiat i liść kasztanowca zwyczajnego. Arkusz zielnikowy (KOR 11551) z Herbarium Instytutu Dendrologii PAN dostępny cyfrowo pod adresem: https://rcin.org.pl/dlibra/publication/123278/edition/96997 powszechnym elementem współczesnego krajobrazu wiejskiego i miejskiego, że często uważa się go za gatunek rodzimy. Pochodzi on jednak $z$ gór na Półwyspie Bałkańskim. W naturze występuje na terenie Albanii, Macedonii i Grecji (Ryc. 2); istnieje również jedna, najprawdopodobniej naturalna, populacja w Bułgarii (AVTzIs i współaut. 2007, Petrova i Vladimirov 2009, ACEVSKI i Simovski 2011). Gatunek ten jest reliktem trzeciorzędowym. Przed okresem zlodowaceń wystepował na terenie niemal całej Europy, również w Polsce, a także w zachodniej

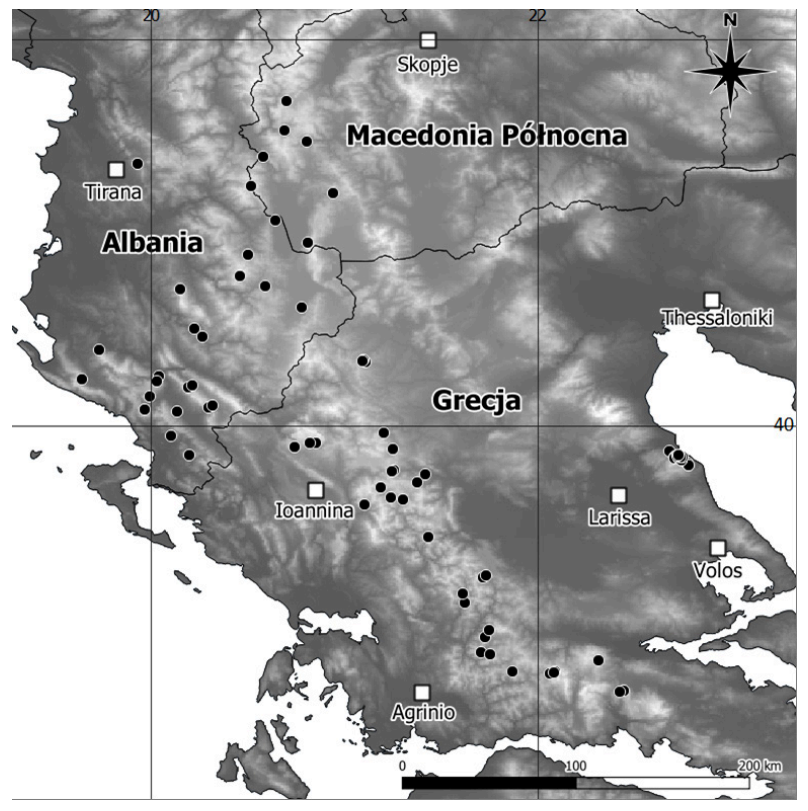

Ryc. 2. Lokalizacja naturalnych populacji kasztanowca zwyczajnego na terenie Grecji, Albanii i Macedonii Północnej (czarne kropki). 
Azji i północnej Afryce (MALEY 1980, MiJARRA i współaut. 2007). W wyniku zmian klimatycznych został zepchnięty do niewielkich obszarów o stabilnych warunkach (refugiów) i przetrwał do czasów współczesnych jedynie na Bałkanach. Nie udało mu się na nowo skolonizować obszaru Europy, co mogło być spowodowane izolacja ostatnich stanowisk w niedostępnych, górskich obszarach, konkurencja $z$ innymi gatunkami drzewiastymi, a także sama biologia kasztanowca. Gatunek ten posiada ciężkie nasiona i jest zapylany przede wszystkim przez owady o ograniczonym zasięgu lotu, co jest problemem zwłaszcza w górach (THOMAs i współaut. 2019). Interesujący jest fakt, że najbliższym żyjacym krewnym kasztanowca zwyczajnego jest kasztanowiec japoński, Aesculus turbinata Blume, którego zasięg jest oddalony od Europy o tysiące kilometrów (XIANG i współaut. 1998). Może to uzmysłowić, jak szeroko rozpowszechniony musiał być ten rodzaj przed okresem zlodowaceń (HARRIS i współaut. 2014).

\section{ODKRYCIE I PIERWSZE OPISY GATUNKU}

Kasztanowiec $\mathrm{z}$ powodu swojego atrakcyjnego wyglądu wzbudził zainteresowanie w czasach świetności Imperium Osmańskiego. Jak dotąd nieznane jest pochodzenie tego gatunku w Stambule; być może trafił tam z Albanii, razem $z$ ogrodnikami $z$ tego regionu (BOYACI 2001), lecz to $z$ tego miasta rozprzestrzenił się na cała Europę. Pierwsze informacje na temat gatunku dotarly w 1557 r. do Pragi, razem z listem lekarza Willema Quackelbeena, który towarzyszył ambasadorowi cesarza Ferdynanda I na dworze sułtana Sulejmana II (LACK 2000). W liście napisanym 26 lipca 1557 r. i wysłanym do mieszkajaccego w Pradze innego lekarza, Pietro Andrea Mattioli, autor opisuje pokrótce kasztanowiec i wspomina, że rośnie on w Istambule powszechnie, chociaż nie należy do lokalnej flory. Drzewo to jest wciąz bardzo popularne $\mathrm{w}$ tym mieście i stare okazy można zobaczyć w parku Gülhane przy palacu Topkapi (BOYACI 2001). Możliwe, że do listu Quackelbeen dołączył nasiona. Świadczyć o tym może odpowiedź, którą Mattioli napisał 4 grudnia i w której zawarł wiele pytań dotyczacych nowopoznanego drzewa (LACK 2000). W 1563 r. MatTioli opublikował w Pradze pierwsza ilustrację przedstawiajaca kasztanowca, która zawarł, wraz z krótkim opisem, w dziele New Kreüterbuch. Informacja o interesujacym, nieznanym gatunku szybko dotarła, za pośrednictwem Mattioliego, do znanego włoskiego lekarza i przyrodnika, Ulisse Aldrovandi (LACK 2000).
Był on wykładowca na Uniwersytecie w Bolonii, a także założycielem ogrodu botanicznego i muzeum przyrodniczego. On również opublikował ilustracje przedstawiająca nowy gatunek, którą zamieścił w dziele Erbario Dipinto (Vol. 5, f. 167, ca. 1560; MAIORONI i współaut. 1995). Do Włoch kasztanowiec zwyczajny sprowadzono być może już przed 1562 r. do prywatnego ogrodu księcia Toskanii (odwiedzajacy wtedy Florencję szwajcarski botanik Jean Bauhin wspomina o kasztanowcu), na pewno zaś dotarł w 1569 r. do Bolonii (BAUHIN i CHERLER 1650). Arkusz zielnikowy $z$ czasów Aldrovandiego, zawierający liść kasztanowca, jest przechowywany do dzisiaj $\mathrm{w}$ herbarium uniwersyteckim w Bolonii. Nasiona lub młode okazy znalazły się również w ogrodzie botanicznym w Padwie, skad G. A. Cortuso wysłał do Bolonii rysunek przedstawiajacy ten gatunek (DE TONI 1922). Prawdopodobnie także w Pizie bardzo wcześnie rozpoczęto uprawę kasztanowca zwyczajnego. Świadcza o tym wzmianki w literaturze: Gaetano Savi opisał wielki, stary okaz kasztanowca przy wejściu do ogrodu botanicznego (SAVI 1811).

Żadne $z$ włoskich miast nie zostało jednak głównym źródłem, $z$ którego kasztanowiec mógłby rozprzestrzenić się na cały kontynent. Tym źródłem stał się natomiast cesarski Wiedeń, skąd znana jest pierwsza pewna uprawa kasztanowca. Pierwsze żywe okazy znalazły się w ogrodzie cesarza Maksymiliana II być może już w 1576 r., na pewno zaś trafily tam w 1581 r., o czym wspomina Carolus Clusius (Charles de L'Écluse), wybitny francuski botanik (CLUSIUS 1583). Z Wiednia kasztanowiec dość szybko rozprzestrzenił się do parków w całej Europie. Do Francji dotarł w 1615 r. i w krótkim czasie po introdukcji zapanowała moda na obsadzanie tym gatunkiem całych alei, prowadzacych do pałaców arystokracji (LOENHART 2002). Do Anglii został sprowadzony prawdopodobnie $\mathrm{w}$ podobnym okresie, zaś z pewnością rósł w $1633 \mathrm{r}$. $\mathrm{w}$ ogrodzie Johna Tradescanta (LEATHART 1991). Na Wyspach Brytyjskich kasztanowiec także zdobył popularność i był chętnie sadzony w parkach i wzdłuż dróg. W Niemczech kasztanowiec stał się bardzo popularny w XVIII w., kiedy powstawały obsadzane tym gatunkiem barokowe aleje; dziś stanowi częsty widok w bawarskich ogródkach piwnych (HERzOG 2005). Kasztanowiec zwyczajny rozpowszechnił się nie tylko w Europie, ale również na terenach o sprzyjającym klimacie $w$ innych częściach świata. Do Ameryki Północnej sprowadzono go prawdopodobnie po raz pierwszy w 1746 r. do Filadelfii (ANONIM 1925); rozpowszechnił się w USA po 1828 r., 
jednak został wyparty przez kasztanowiec czerwony (Aesculus x carnea Hayne), który jest mieszańcem europejskiego gatunku $z$ amerykańskim kasztanowcem krwistym (A. pavia L.). Dzisiaj kasztanowiec zwyczajny rośnie w parkach w Chinach i Nowej Zelandii, a także w zachodniej Azji. Do popularności tego gatunku przyczyniły się nie tylko względy dekoracyjne, ale także stosunkowo niewielkie wymagania siedliskowe - kasztanowiec jest w stanie rosnać w zanieczyszczonych miastach, toleruje niską wilgotność powietrza i ubogie gleby oraz potrafi przetrwać zimy nawet w Skandynawii (THOMAS i wspólaut. 2019). Łatwo rozmnaża się go $z$ nasion, jednak bardzo źle znosi przesuszenie (PAMMENTER i BERJAK 1999).

\section{KASZTANOWIEC W POLSCE}

Do Polski kasztanowiec mógł trafić już w pod koniec XVI w. za sprawa króla Stefana Batorego, który nakazał swojemu ogrodnikowi, Lorenzo Bozetho, posadzenie tych drzew w Łobzowie pod Krakowem (SENETA 1991). Nieco później Jan III Sobieski sprowadził najprawdopodobniej pewna liczbę sadzonek w celu upiększenia swojego prywatnego ogrodu. Gatunek ten stał się szybko popularny w naszym kraju i był bardzo chętnie sadzony ze względu na swój atrakcyjny wygląd. Motyw liści, owoców czy kwiatów często był wykorzystywany w sztuce i architekturze (ZEMANEK i współaut. 2009). Powstało też wiele słynnych alei $z$ tym gatunkiem, między innymi w Warszawie (Aleja Kasztanowa założona w 1815 r.), Szymanowie czy Komorznie. Wiele kasztanowców w Polsce ma status pomnika przyrody (na początku 2019 r. były to 622 drzewa, zgodnie $z$ Centralnym Rejestrem Form Ochrony Przyrody). Najstarszym żyjacym w naszym kraju okazem jest prawdopodobnie „Benedykt” $z$ Lubinia, rosnacy $\mathrm{w}$ pobliżu opactwa benedyktyńskiego i majacy ponad 250 lat (PACYNIAK 1992).

Pierwszy znany opis kasztanowca w języku polskim pochodzi $z$ dzieła Krzysztofa Kluka pod tytułem Dykcyonarz roślinny (KLUK 1786) (Ryc. 3). Autor opisuje tam gatunek i podaje jego dekoracyjne zalety, a także wymienia możliwe zastosowania różnych części rośliny. Drewno, według Kluka, nadaje się co najwyżej na niewielkie meble, ponieważ jest miękkie i nietrwałe. Znacznie więcej pożytku było $z$ nasion: mogły stanowić surowiec do produkcji krochmalu, kleju i środków do bielenia lnianego płótna. Opisany jest również sposób w jaki można $z$ trujacych i bardzo gorzkich nasion uzyskać substytut mąki, co wymagało jednak długotrwałego przemywania rozcię-

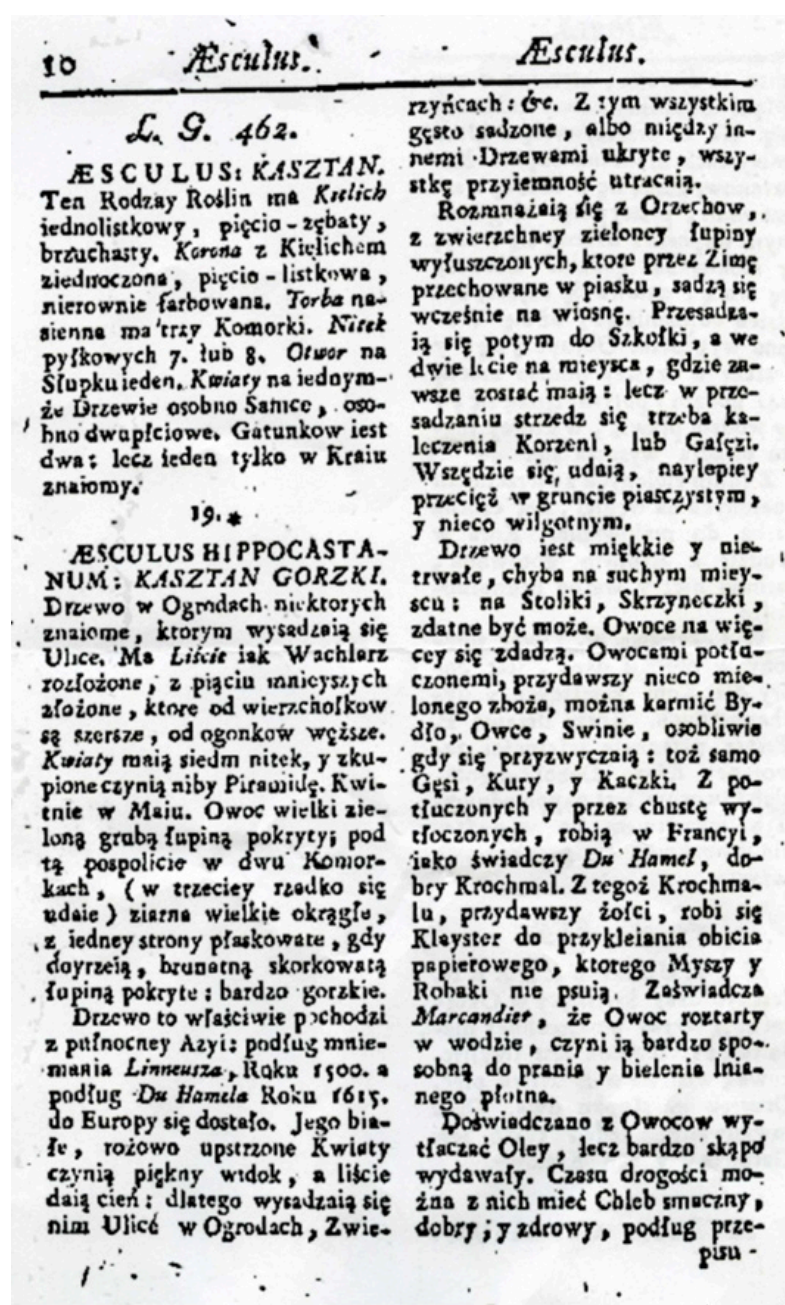

Ryc. 3. Reprodukcja oryginalnej strony $z$ dzieła „Dykcyonarz roslinny” (KLUK 1805).

tych nasion $\mathrm{w}$ wodzie $\mathrm{z}$ wapnem. Wykorzystywane były też „łupiny”, a właściwie kolczaste torebki (uzyskiwano $z$ nich czarna farbę) oraz kora (która $z$ kolei farbowała wełnę na kolor brunatnożółty). Wymieniono także zastosowanie nasion kasztanowca do leczenia kaszlu u koni, co czyniono już w Imperium Osmańskim (LACK 2002). Ta właściwość stała się zresztą źródłem łacińskiej nazwy gatunku (w starożytnej grece hippos - koń), a także nazw w wielu inny jezzykach (ang. horse-chestnut, ros. конский каштан, wł. L’ippocastano). Dzisiaj również wykorzystuje się kasztanowiec do leczenia, ale ludzi. Escyna, główna saponina znajdujaca się $\mathrm{w}$ nasionach, poprawia elastyczność ścian naczyń żylnych, działa przeciwobrzękowo i przeciwzapalnie (ZHANG i współaut. 2010, FOCA i współaut. 2011). Wykorzystywana jest m.in. w środkach do leczenia żylaków. Ekstrakt $z$ nasion jest używany także w kosmetyce, do produkcji mydła, szamponów czy kremów. Dekokt (czyli wywar) z kory i liści kaszta- 
nowca, a także nalewka na nasionach, sa używane w medycynie ludowej Albanii jako środek na reumatyzm (FOCA i współaut. 2011, Mustafa i współaut. 2020).

\section{NATURALNE POPULACJE}

Wszystkie drzewa rosnace dziś w europejskich parkach pochodza prawdopodobnie $z$ niewielkiej liczby pierwotnych źródeł. Przez długi czas naturalne, bałkańskie populacje pozostawały nieznane. Powszechnie uważano, że kasztanowiec pochodzi z Azji i występuje naturalnie u podnóża Himalajów (gdzie można znaleźć pokrewny gatunek, Aesculus indica (Wall. ex Cambess.) Hook. W polskim dziele pod tytułem Opisanie drzew $i$ krzewów leśnych Królestwa Polskiego, napisanym przez Michała Szuberta, autor sugerował, że „gorzki kasztan” pochodzi z Anatolii (SZUBERT 1827). Pierwsze doniesienia o występowaniu tego gatunku w naturze na terenie Bałkanów, które John Hawkins zamieścił w dziele Florae Graecae Prodromus, zostały zignorowane (SIBTHORP i SMITH 18061816). Powodem był prawdopodobnie brak arkuszy zielnikowych $z$ tej wyprawy, które mogłyby poświadczyć odkrycie naturalnych stanowisk. Istnienie izolowanych i niewielkich populacji w niedostępnych górach Epiru zostało potwierdzone dopiero pod koniec XIX w. Ponad 80 lat po odkryciu naturalnych populacji przez Hawkinsa, Theodor von Heldreich, dyrektor ogrodu botanicznego w Atenach, opisał pięć stanowisk gatunku (HELDREICH 1880). Był to efekt zorganizowanej przez niego ekspedycji, która miała na celu poznanie flory Grecji. Kraj ten, na mocy traktatu berlińskiego z 1878 r., uzyskiwał od Imperium Osmańskiego tereny Tesalii i południowego Epiru, gdzie znajdowały się stanowiska kasztanowca. Arkusze zielnikowe zebrane podczas tej wyprawy, oznaczone data 11 sierpnia 1879 r., sa przechowywane w kolekcji Muzeum Historii Naturalnej w Wiedniu. Ponieważ Heldreich znalazł drzewa na terenie trudnodostępnym i całkowicie dzikim, był pewien, że populacje te sa naturalne. Wielu badaczy przybyło do Epiru, aby potwierdzić to odkrycie, m.in. Antonio Baldacci, profesor z Bolonii, który później opisał populacje na terenie dzisiejszej Albanii (BALDACCI 1936). Stanowiska znajdujące się poza Grecja zostały jednak odkryte dopiero w XX w..

\section{ZAGROŻENIA}

W naturalnym środowisku kasztanowiec zwyczajny rośnie w górskich lasach liściastych, na wysokości 1000-1200 m n.p.m., na żyznym, średnio wilgotnym lub wilgotnym

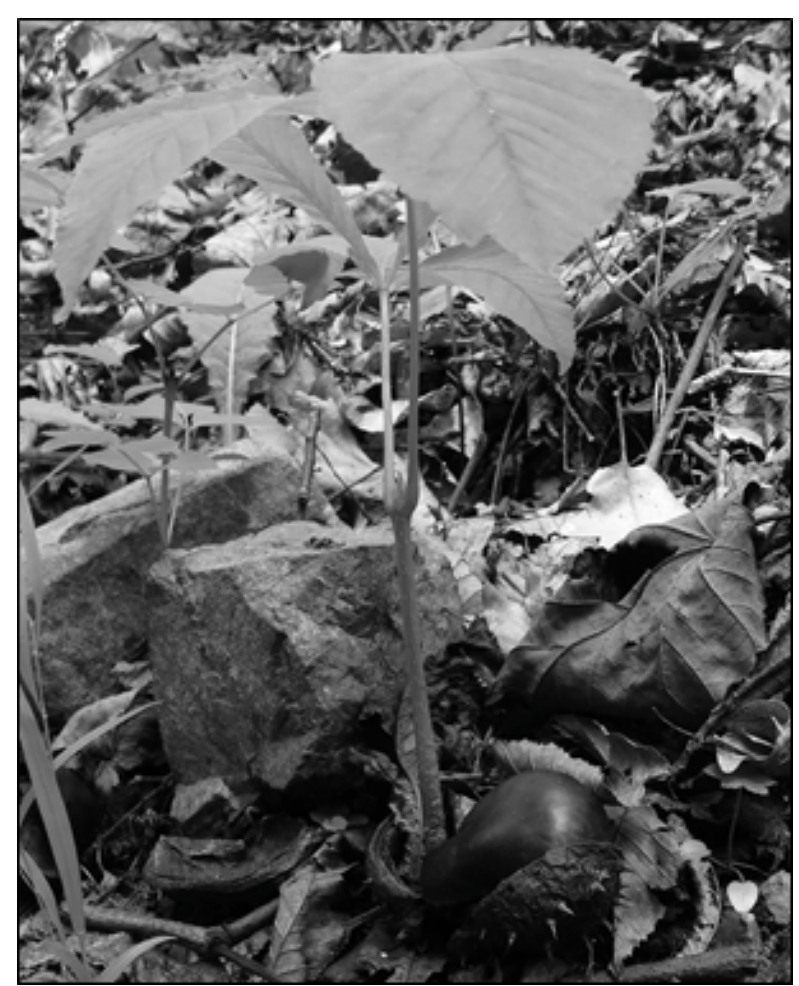

Ryc. 4. Młody osobnik kasztanowca zwyczajnego (fot. G. Iszkuło).

podłożu, zwykle wzdłuż cieków wodnych, w towarzystwie buków, dębów, jesionów, lip i jodeł (THOMAs i współaut. 2019). Zajmuje także trudnodostępne miejsca na stokach. Niestety, jest gatunkiem o spadającej liczebności; dorosłych drzew jest prawdopodobnie mniej niż 2500 (RAVAzZI i CAUDULlO 2016). $\mathrm{Na}$ wielu stanowiskach nie zaobserwowano siewek i młodych osobników (Ryc. 4). Międzynarodowa Unia Ochrony Przyrody (IUCN) wpisała kasztanowiec na listę gatunków zagrożonych, na której w 2018 r. miał status VU (ang. vulnerable; narażony) (ALLEN i KHELA 2017). Sytuacja jest nieco paradoksalna, ponieważ $z$ jednej strony kasztanowiec zwyczajny jest niezwykle rozpowszechniony i znajduje się w ciagłej uprawie od XVI w., $z$ drugiej natomiast, zmniejsza swoja liczebność w naturze. Dużym zagrożeniem jest dla niego gospodarka wodna, zwłaszcza na terenie Grecji - szybko rozwijające się rolnictwo wymaga dużej ilości wody, co prowadzi do zanikania górskich strumieni (BALTAS 2008). Gatunek ten nie został jak dotąd ujęty na Czerwonej Liście Grecji, co sprawia, że całe populacje moga ulec zniszczeniu $z$ powodu rozwoju infrastruktury (PHITOS i współaut. 2009). Pocieszający może być jednak fakt, że około połowa stanowisk w Grecji znajduje się w obrębie rezerwatów i parków narodowych (AvTZIS i współaut. 2007). Jedyna bułgarska populacja jest chroniona w rezerwacie, natomiast trzy macedońskie znajduja się 
w parku narodowym (PETROVA i VLADIMIROV 2009, ACEVSKI i SimovsKI 2011). Wszystkie te stanowiska moga być niestety zagrożone przez spodziewane zmiany klimatu, ponieważ przewiduje się znaczne zmniejszenie opadów na obszarze południowych Bałkanów (GIORGI i LiONELLO 2008). Może to spowodować zanikanie odpowiednich siedlisk, a także zwiększyć ryzyko pożarów, na które kasztanowiec jest wyjątkowo wrażliwy $z$ powodu niewielkiej grubości kory. Byłaby to wielka strata dla gatunku - naturalne stanowiska stanowią bezcenny rezerwuar zmienności genetycznej (WALAS i współaut. 2019).

Drzewa w parkach i ogrodach także sa zagrożone. Od wielu lat problem stanowi szrotówek kasztanowcowiaczek (Cameraria ohridella Deschka \& Dimić), motyl, którego larwy żerują na liściach kasztanowca, co prowadzi do ich zniszczenia (DESCHKA i DIMIĆ 1986, THALMANN i współaut. 2003, JAGIEŁŁO i współaut. 2019) (Ryc. 5). Rozprzestrzenił się on bardzo szybko (opisany został w latach 80. XX w.) i poczatkowo nie miał niemal żadnych naturalnych wrogów. Owad ten jest tak uciażliwy, że został umieszczony na liście stu najgroźniejszych gatunków inwazyjnych Europy (Hulme 2009), obok stonki ziemniaczanej (Leptinotarsa decemlineata Say) czy czeremchy amerykańskiej (Prunus serotina Michx). Powstało także wiele projektów i badań majacych na celu wprowadzanie skutecznych metod zwalczania tego szkodnika, np. europejski projekt CONTROCAM („Control of Cameraria”) (HEITLAND i FREISE 2003) czy polska akcja „Pomóżmy kasztanowcom" organizowana w latach 2005-2014. Ze względu na duże zagrożenie, jakie stwarza szrotówek, pojawiło się wiele metod redukcji populacji tego szkodnika

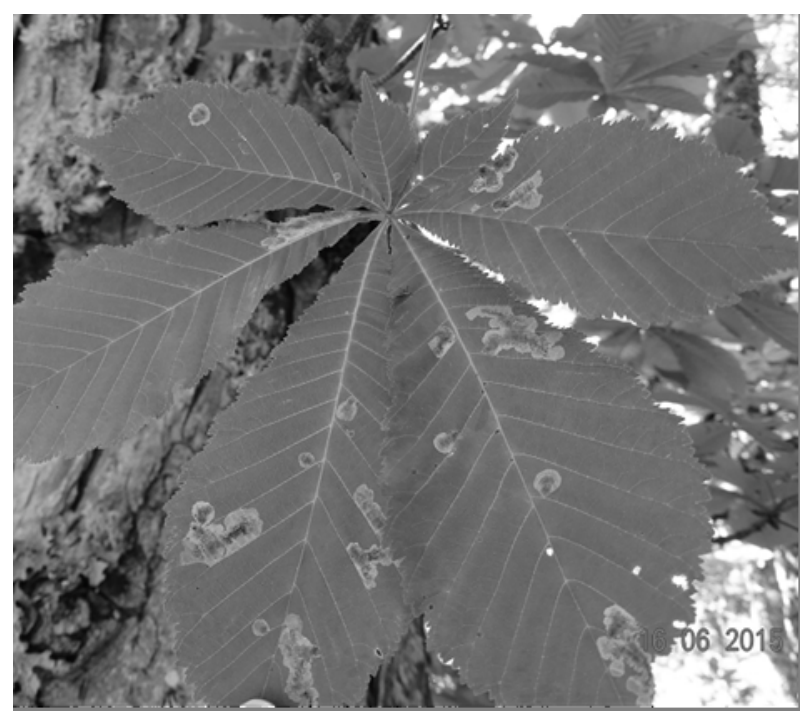

Ryc. 5. Liść porażony przez szrotówka kasztanowcowiaczka (fot. G. Iszkuło).
(KosiBowicz 2005). Najprostsza i najskuteczniejsza metoda jest grabienie i palenie opadłych liści kasztanowca. Niestety, prowadzi ona także do zniszczenia wielu pożytecznych owadów. Pewna modyfikacją tej metody jest termofilne kompostowanie liści razem $z$ osadami ściekowymi (ŁowińsKI i DACH 2008). Innym, popularnym sposobem jest lepowanie pni. Można stosować także pułapki feromonowe, co jest metoda bardziej ukierunkowana na konkretny gatunek (KosiBOWICZ 2005). Stosowane sa także iniekcje drzew środkami owadobójczymi, które moga działać przez wiele lat (JAGIEŁŁO i współaut. 2019). Wielu badaczy pracuje intensywnie nad lepszym poznaniem szrotówka i jego wpływu na kasztanowce, co daje nadzieję na zwycięstwo w walce ze szkodnikiem.

Szrotówek kasztanowcowiaczek atakuje również naturalne stanowiska kasztanowca, chociaż część $z$ nich jest słabo porażona lub nawet wolna od szrotówka, co może świadczyć o występowaniu naturalnych mechanizmów regulacji populacji szkodnika (AVTzIs i AvTZIS 2003, WALAS i współaut. 2018). Owad ten jest atakowany przez różne pasożytnicze owady, takie jak bleskotki (Chalcidoidea), przez nicienie $z$ rodzaju Steinernema oraz przez choroby grzybowe (KosiBowicz 2005, KALMUS i współaut. 2008, LERCHE i współaut. 2008, HERNÁNDEZ-LÓPEZ i współaut. 2012, MATUSKA-ŁYŻWA i współaut. 2015). Wiadomo, że na larwach i motylach szrotówka może żerować wiele drapieżnych pajęczaków i owadów: złotooki (Chrysopa sp.), szerszenie (Vespa sp.) i mrówki Crematogaster scutellaris (Oliver); również niektóre ptaki, takie jak sikorki (Parus sp.), pokrzewki (Sylvia sp.) oraz wróble (Paser sp.) zjadaja szrotówka (RADEGHIERI 2004, GRABENWEGER i współaut. 2005, KosiBowicz 2005). Obserwacje prowadzone na sztucznych stanowiskach wykazały, że łupem ptaków pada od $2 \%$ do 4\% tych owadów (GRABENWEGER i współaut. 2005). Niestety, szrotówek nie jest jedynym problemem. Kasztanowiec jest atakowany także przez choroby, takie jak czekoladowa plamistość liści (powodowana przez grzyb Guignardia aesculi) czy bakteryjna choroba wywoływana przez patogen Pseudomonas syringae pv. aesculi (GREEN i współaut. 2009, PASTIRČÁKOVÁ i współaut. 2009).

\section{PODSUMOWANIE}

Kasztanowiec jest drzewem ważnym dla ogrodnictwa i medycyny; jest też istotnym komponentem naturalnych ekosystemów leśnych Półwyspu Bałkańskiego i częścia biologicznego dziedzictwa Europy. W Polsce stanowi cenny i piękny element parków i ogrodów. Czy można wyobrazić sobie wiosnę 
bez ukwieconych alei? Kwitnace na biało drzewa stały się symbolem zbliżających się egzaminów maturalnych, a charakterystyczne liście stanowia częsty element zdobniczy. Jesienia nasiona kasztanowca sa chętnie zbierane przez dzieci, które wykonuja $z$ nich małe dzieła sztuki. Miejmy nadzieję, że podejmowane próby zachowania tego gatunku zakończą się sukcesem i również przyszłe pokolenia będa mogły cieszyć się widokiem tego urokliwego drzewa.

\section{Streszczenie}

Kasztanowiec zwyczajny (Aesculus hippocastanum L.), popularne drzewo ozdobne, został sprowadzony do centralnej Europy $\mathrm{z}$ Istambułu. Pojawił się pod koniec XVI w. w Wiedniu, Bolonii, Padwie i Pradze. Szybko stał się popularny i w krótkim czasie dotarł do Anglii, Niemiec i Francji. W Polsce po raz pierwszy znalazł się prawdopodobnie w XVI w., sprowadzony przez króla Stefana Batorego. Naturalne stanowiska tego gatunku w górzystych obszarach Bałkanów zostały odkryte dopiero $\mathrm{w}$ XIX w. Występuje on tam $\mathrm{w}$ rozproszonych populacjach o zmniejszajaccej się liczebności. Ten reliktowy gatunek jest bardzo ceniony w parkach ze względu na walory dekoracyjne i niewielkie wymagania siedliskowe; ma również znaczenie w przemyśle farmaceutycznym. Inwazja motyla, szrotówka kasztanowcowiaczka, spowodowała spadek wartości dekoracyjnych i zagrożenie kasztanowców w całej Europie. Przewidywane zmiany klimatu moga również stanowić niebezpieczeństwo dla tego gatunku.

\section{LITERATURA}

ACEVSKI J., SimOVsKI B., 2012. Forest associations of the National Park Mavrovo in the Republic of Macedonia. [W:] Proceedings of the International Conference Integrated Management of Environmental Resources - Suceava, November 2011. HoRODNIC S.A., DUDUMAM M.-L., PAlaghianu C. (red.). Suceava: Editura Universității "Ștefancel Mare", 17-27.

Allen D., KHEla S., 2017. Aesculus hippocastanum (errata version published in 2018). The IUCN Red List of Threatened Species 2017.

ANONIM, 1925. Horse-chestnuts and buckeyes. Bulletin of Popular Information, Arnold Arboretum, Harvard University, New Series 11, 29-30.

AVtZIS N., AvTZIS D., 2003. The Attack of Aesculus hippocastanum L. by Cameraria ohridella Deschka and Dimic (Lepidoptera: Gracillariidae) in Greece. [W]: Proceedings: Ecology, Survey and Management of Forest Insects Kraków, September 2002. McManus M. L., LiEBHOLD A. M. (red.). Kraków, Polska: Gen. Tech. Rep. NE-311; Newtown Square, PA, USA: US Dept. of Agriculture, Forest Service, Northeastern Res. Station 1-5, 311.

Avtzis N. D., Avtzis D. N., Vergos S. G., DiAMANDIS S., 2007. A contribution to the natural distribution of Aesculus hippocastanum (Hippocastanaceae) in Greece. Phytologia Balcanica 13, 183-187.

BALDACCI A., 1935. Sull'Aesculus hippocastanum L.: a proposito di un relitto dendroide eurasiatico della flora Balcanica e specialmente Ilirico-ellenica. Memorie della Regia Academia delle Scienze dell Istituto di Bologna 9, 87108.

BALTAS E. A., 2008. Climatic conditions and availability of water resources in Greece. Int. J. Water Resour. Develop. 24, 635-649.

BAUHIN I., ChERLER I. H., 1650. Historia Plantanarum Universalis 1 (2). Ebroduni.

BOYACI M., 2001. Topkapı sarayı külliyesi ve bahçesinde bulunan süs bitkilerinin sistematik kompozisyonu. Marmara Üniversitesi.

Clusius C., 1583. Rariorum aliquot stripium, per Pannoniam, Austrian \& vicinas quasdam prouincias obseruatarum Historia. C. Plantinus, Antverpiae.

DESCHKA G., DIMIĆ N., 1986. Cameraria ohridella n. sp. aus Mazedonien, Jugoslawien (Lepidoptera, Lithocelletidae). Acta Entomologica Jugoslavica 22, 11-23.

DE TONI G. B., 1922. Spigolature Aldrovandiane XIX Il botanico padovano Giacomo Antonio Cortuso nelle sue relazioni con Ulisse Aldrovandi e con altri naturalisti. [W:] Monografie storiche sullo studio di Padova. Contributo del $R$. Istituto Veneto di scienze, lettere ed arti alla celebrazione del VII centenario della università. ANONIM (red.). C. Ferrari, Venezia, 217-249.

Foca G., UlRici A., COCChi M., Durante C., Vigni M.L., MARCheTTI A., SighinOlfi S., TASSI L., 2011. Seeds of horse chestnut (Aesculus hippocastanum L.) and their possible utilization for human consumption. [W:] Nuts and Seeds in Health and Disease Prevention. PREEDY V. R., WATSON R. R. (red.). Academic Press, 653661.

GioRGi F., LiONELlo P., 2008. Climate change projections for the Mediterranean region. Global Planet. Change 63, 90-104.

Grabenweger G., Kehrli P., SChlick-Steiner B., Steiner F., STolz M., BACHeR S., 2005. Predator complex of the horse chestnut leafminer Cameraria ohridella: identification and impact assessment. J. Appl. Entomol. 129, 353-362.

Green S., LaUe B., Fossdal C. G., A'HARA S. W., CotTrell J. E., 2009. Infection of horse chestnut (Aesculus hippocastanum) by Pseudomonas syringae pv. aesculi and its detection by quantitative real $\square$ time $P C R$. Plant Pathol. 58, 731-744.

HARRIS A. J., PAPEŞ M., GAO Y. D., WATSON L., 2014. Estimating paleoenvironments using ecological niche models of nearest living relatives: A case study of Eocene Aesculus L. J. Syst. Evol. 52, 16-34.

HeITLAND W., FREISE J. F., 2003. Das EU-Projekt CONTROCAM (Control of Cameraria). Nachrichtenblatt des Deutschen Pflanzenschutzdienstes 55, 205-208.

HELDREICH T., 1880. Beiträge zur Kenntnis des Vaterlandes und der geographischen Verbeitung der Rosskastanie, des Nussbaums und der Buche. Verhandlungen des Botanischen Vereins der Provinz Brandenburg 21, 139153.

HeRnÁndez-López A, Rougerie R., Augustin S., LEES D.C., TOMOV R., KenIS M., COTA, E., KullaJ E., Hansson C., GrabenWEger G., RoQues A., LóPEZ-VAamonde C., 2012. Host tracking or cryptic adaptation? Phylogeography of Pediobius saulius (Hymenoptera, Eulophidae), a parasitoid of the highly invasive horsechestnut leafminer: Parasitoid host races. Evolut. Appl. 5, 256-269.

HERZOG R., 2005. Die Rosskastanie in historischen Gärten - Beispiele aus Ost- und Süddeutschland. LWF-Wissen 48, 45-51. 
Hulme P. E. 2009. Handbook of alien species in Europe. Springer, Dordrecht

JAGIEŁLO R., WALCZAK U., ISZKUŁO G., KAROLEWSKI P., BARANIAK E., GIERTYCH M. J., 2019. Impact of Cameraria ohridella on Aesculus hippocastanum growth and long-term effects of trunk injection with pesticides. Int. J. Pest Manage. 65, 33-43.

Kalmus M., SERMANN H., LERChE S., BÜTTNER C., 2008. Efficacy of entomopathogenic fungi against larvae of the horse chestnut leafminer Cameraria ohridella Deschka \& Dimic, 1986 (Lepidoptera, Gracillariidae). IOBC/wprs Bulletin 31, 220-222.

KLUK K., 1786. Dykcyonarz roslinny: $w$ którym podług układu Linneusza sa opisane rosliny nietylko kraiowe dzikie, pożyteczne, albo szkodliwe: Na roli, $w$ ogrodach, oranżeryach, utrzymywane: Ale oraz $i$ cudzoziemskie, ktoreby $w$ kraiu poźyteczne byc mogty: Albo $z$ ktorych mamy lekarstwa, korzenie, farby...: $z$ poprzedzaiacym wykładem słów Botanicznych, $i$ kilkokrotnym na końcu Reiestrem. A-E (Vol. 1). Drukarnia Xięży Piarów, Warszawa.

KosiBowicz M., 2005. Szrotówek kasztanowcowiaczek Cameraria ohridella Deschka \& Dimiae (Lepidoptera, Gracillariidae), nowy inwazyjny szkodnik kasztanowca białego Aesculus hippocastanum L. $w$ Polsce - biologia $i$ metody zwalczania. Leśne Prace Badawcze, 2, 121132

LACK H. W., 2000. Lilac and Horse-chestnut: Discovery and Rediscovery. Curtis's Botanical Magazine 17, 109-141.

LACK H. W., 2002. The discovery and rediscovery of the horse chestnut. Arnoldia 61, 15-19.

LEATHART S., 1991. Whence our trees. London, UK, Foulsham.

Lerche S., SERMANN H., BÜtTner C., 2008. Persistence of the entomopathogenic fungus Lecanicillium muscarium Zare \& Gams under ambient conditions in the field. Commun. Agricult. Appl. Biol. Sci. 74, 353-356.

LOENHART K. K., 2002. Aesculus hippocastanum: The Handsome (and Useful) Horse-chestnut. Arnoldia 61, 20-22.

ŁoWIŃSKI Ł., DACH J., 2006. Termofilne kompostowanie liści kasztanowca $z$ osadami ściekowymi jako metoda unieszkodliwiania zagrożenia szrotówkiem kasztanowcowiaczkiem. J. Res. Appl. Agricult. Engine. 51, 108-111.

MALEY J., 1980. Les changements climatiques de la fin du Tertiaire en Afrique: leur conséquence sur l'apparition du Sahara et de sa végétation. [W:] The Sahara and the Nile: quaternary environments and prehistoric occupation in Northern Africa. Williams M. A. J., Faure H. (red.) Rotterdam, Balkema, 63-86.

MAIORONI A., 1995. Catalogazione e prime classificazioni. Flortecnica 12 (Suppl.), 105-366.

MatTioli P. A., 1563. New Kreüterbuch mit den allerschönsten und artlichsen Figuren aller Gewechss, dergleichen vormals in keener Sprach nie an Tag kommen. G. Melantrich, Prag.

MATUSKA-ŁYŻWA J., KACA W., ŻARNOWIEC P., 2015. Biological activity of wild isolates of entomopathogenic nematodes to horse- chestnut leaf Miner (Cameraria ohridella). Pol. J. Environ. Stud. 24, 1181-1184.

MiJARRA J. M. P., MANZANEQUe F. G., Morla C., 2007. Survival and long-term maintenance of tertiary trees in the Iberian Peninsula during the Pleistocene: first record of Aesculus L.(Hippocastanaceae) in Spain. Vegetat. History Archaeobot. 17, 351-364.
Mustafa B., Hajdari A., Pulaj B., Quave C. L., PIERONI A., 2020. Medical and food ethnobotany among Albanians and Serbs living in the Shtërpcë/Štrpce area, South Kosovo. J. Herbal Med. 22, doi.org/10.1016/j.hermed.2020.100344.

PaCYNIAK C., 1992. Najstarsze drzewa w Polsce. Warszawa, Wydawnictwo PTTK „Kraj”.

PAMMENTER N. W., BERJAK P., 1999. A review of recalcitrant seed physiology in relation to desiccation-tolerance mechanisms. Seed Sci. Res. 9, 13-38.

PASTIRČÁKOVÁ K., PASTiRČÁK M., Celar F., SHiN H. D., 2009. Guignardia aesculi on species of Aesculus: new records from Europe and Asia. Mycotaxon 108, 287-296.

Petrova A., Vladimirov V., 2009. Red List of Bulgarian vascular plants. Phytol. Balcanica 15, 63-94.

Phitos D., Constantinidis T., KAMARI G., 2009. The Red Data Book of Rare and Threatened Plants of Greece. Hellenic Botanical Society, Patras.

RADEGHIERI P., 2004. Cameraria ohridella (Lepidoptera Gracillariidae) predation by Crematogaster scutellaris (Hymenoptera Formicidae) in Northern Italy (Preliminary note). Bull. Insectol. 57, 63-64.

Ravazzi C., CAUdullo G., 2016. Aesculus hippocastanum in Europe: distribution, habitat, usage and threats. [W:] European Atlas of Forest Tree Species. SAN-MiguEL-AYANZ J., DE Rigo D., Caudullo G., Houston DurRant T., MAURI A. (red). Publication Office of the European Union, 60.

Savi G., 1811. Trattato degli alberi della Toscana. Pisa.

Seneta W., 1991. Drzewa $i$ krzewy liściaste. A-B. Warszawa, Wydawnictwo Naukowe PWN.

SiBTHORP J., SMITH J. E., 1806-1813. Florae Graecae prodromus. Londyn.

SZUBERT M., 1827. Opisanie drzew i krzewów leśnych Królestwa Polskiego. N. Glücksberg, Warszawa.

Thalmann C., Freise J., Heitland W., Bacher S., 2003. Effects of defoliation by horse chestnut leafminer (Cameraria ohridella) on reproduction in Aesculus hippocastanum. Trees 17, 383388.

Thomas P. A., Alhamd O., Iszkulo G., Dering M., MukAssaBI T. A., 2019. Biological Flora of the British Isles: Aesculus hippocastanum. J. Ecol. 107, 992-1030.

Walas Ł., Dering M., Ganatsas P., Pietras M., PERS-KAMCZYC E., IsZKUŁO G., 2018. The present status and potential distribution of relict populations of Aesculus hippocastanum L. in Greece and the diverse infestation by Cameraria ohridella Deschka \& Dimić. Plant Biosyst. 152, 1048-1058.

Walas Ł., Ganatsas P., IsZKulo G., Thomas P. A., DERING M., 2019. Spatial genetic structure and diversity of natural populations of Aesculus hippocastanum L. in Greece. PloS One 14, doi: 10.1371/journal.pone.0226225.

Xiang Q. Y., CRaWford D. J., Wolfe A. D., TANG Y. C., Depamphilis C. W., 1998. Origin and biogeography of Aesculus L.(Hippocastanaceae): a molecular phylogenetic perspective. Evolution 52, 988-997.

ZEMANEK A., ZEMANEK B., HARMATA K., MADEJA J., KLEPACKI P., 2009. Selected foreign plants in old Polish botanical literature, customs and art (Acorus calamus, Aesculus hippocastanum, Cannabis sativa, Fagopyrum, Helianthus anuus, Iris). [W:] Plants and culture: seeds of 
the cultural heritage of Europe. MOREL J.-P., MERCURI A. M. (red.). Edipuglia, Bari, 179193.

KOSMOS Vol. 70, 1, 27-34, 2021
ZHANG Z., Li S., LIAN X.-Y., 2010. An overview of genus Aesculus L.: Ethnobotany, phytochemistry, and pharmacological activities. Pharmaceut. Crops 1, 24-51.

\section{ŁUKASZ WALAS}

Institute of Dendrology PAS, 5 Parkowa Str., 62-035 Kórnik, E-mail: lukaswalas@man.poznan.pl

THE AMAZING HISTORY OF AN ORDINARY HORSE-CHESTNUT

\section{Sum mary}

Horse-chestnut (Aesculus hippocastanum L.), a popular ornamental tree, was brought to central Europe from Istanbul. It appeared at the end of the sixteenth century in Vienna, Bologna, Padua, and Prague. It quickly became popular and soon reached England, Germany, and France. It was brought to Poland probably by king Stefan Batory in the sixteenth century. The natural stands of this species, in the mountainous areas of the Balkans, were discovered only in the nineteenth century. It occurs there in scattered populations in decline. This relict species is highly valued in parks because of ornamental values and small habitat requirements; it also has significance in the pharmaceutical industry. Invasion of a moth, horse-chestnut leaf miner, resulted in a decrease of the aesthetic value of the tree and pose a threat for the horse-chestnut trees in Europe. Future climate changes may also pose a threat to this species.

Key words: Aesculus hippocastanum, history of botany, horse-chestnut, tertiary relic 